\title{
Potential of plant beneficial bacteria and arbuscular mycorrhizal fungi in phytoremediation of metal-contaminated saline soils
}

\author{
Ying $\mathrm{Ma}^{\mathrm{a}, *}$, Mani Rajkumar ${ }^{\mathrm{b}}$, Rui S. Oliveira ${ }^{\mathrm{a}}$, Chang Zhang ${ }^{\mathrm{c}}$, Helena Freitas ${ }^{\mathrm{a}}$ \\ ${ }^{a}$ Centre for Functional Ecology-Science for People \& the Planet, Department of Life Sciences, University of Coimbra, 3000-456 Coimbra, Portugal \\ ${ }^{\mathrm{b}}$ Department of Environmental Sciences, Bharathiar University, Coimbatore 641046, India \\ c Chuzhou University, Chuzhou 239000, China
}

Phytoremediation has been considered as a promising technique to decontaminate polluted soils. However, climatic stress particularly salinity, is a potential threat to soil properties and plant growth, thus restricting the employment of this technology. The aim of this study was to access the impact of microbial inoculation on phytoremediation of nickel (Ni) contaminated saline soils using Helianthus annuus. Salt resistant plant beneficial bacterium (PBB) Pseudomonas libanensis TR1 and arbuscular mycorrhizal fungus (AMF) Claroideoglomus claroideum BEG210 were used. Inoculation of $P$. libanensis alone or in combination with C. claroideum significantly enhanced plant growth, changed physiological status (e.g. electrolyte leakage, chlorophyll, proline and mal-ondialdehyde contents) as well as $\mathrm{Ni}$ and sodium $\left(\mathrm{Na}^{+}\right)$accumulation potential (e.g. uptake and translocation factor of $\mathrm{Ni}$ and $\mathrm{Na}^{+}$) of $\mathrm{H}$. annuus under $\mathrm{Ni}$ and salinity stress either alone or in combination. These results revealed that bioaugmentation of microbial strains may serve as a preferred strategy for improving phytor-emediation of metal-polluted saline soils.

Keywords: Plant beneficial bacteria Arbuscular mycorrhizal fungi Phytoremediation Metal-contaminated saline soils Helianthus annuus

\section{Introduction}

Phytoremediation is currently considered as a more sustainable approach than physicochemical remediation alternatives for removing/ stabilizing heavy metals (HM) from contaminated soils. The efficiency of phytoremediation to remove HM from soils depends on several factors, such as plant biomass production, metal uptake potential and environmental parameters. As the climatic stress factors in metal-polluted soils have the capability of altering the plant water use and metabolic processes; there will be changes in tolerance and adaptation of remediating plants in metal-contaminated soils. Among the various abiotic stress factors, salinity can adversely impact plant growth and yield by inducing water deficit, ion [sodium $\left(\mathrm{Na}^{+}\right)$and chloride $\left(\mathrm{Cl}^{-}\right)$] phytotoxicity, nutritional disorders [deficiency of potassium $\left(\mathrm{K}^{+}\right)$and calcium $\left.\left(\mathrm{Ca}^{2+}\right)\right]$ and oxidative stress, which consequently reduce plant photosynthetic rate and biomass production [1]. Since the remediating plants have to deal with both heavy metal and salinity stress, the application of phytoremediation technique in metal-contaminated saline soils is often limited because sodium and/or heavy metals at higher concentration cause severe oxidative stress, resulting further reduction in plant growth parameters, photosynthetic rate and stomatal conductance [2].
Microbe-assisted phytoremediation is an emerging but under-utilized technology that can be exploited to help plant survival, grow and accumulate metals under various environmental stress conditions [3-5]. Similarly, under salinity stress in metal-polluted soils, multiple stress resistant plant-growth promoting microorganisms (PGPM) in association with host plants might be used to remediate metal-contaminated saline soils.

PGPM such as plant beneficial bacteria (PBB) and arbuscular mycorrhizal fungi (AMF) can enhance plant resistance against various environmental stresses (e.g. salinity, drought, extreme temperatures, and HM), consequently improving their growth and yield [4,6]. PGPM can stimulate plant growth and development under both normal and stressful conditions via various mechanisms, including solubilization and mineralization of nutrients [nitrogen $(\mathrm{N})$, phosphorus $(\mathrm{P})$ and potassium (K)]; production of phytohormones [e.g. indole-3-acetic acid (IAA), cytokinins (CK) and gibberellins] and siderophores; biological control (production of inhibitory allelochemicals and induction of systemic resistance) [3,7]. Although many studies have demonstrated that inoculation of PBB or AMF could promote the germination, growth, and development of various plant species, such as Arabidopsis thaliana, Brassica juncea, Capsicum annuum, Gossypium hirsutum, Helianthus annuus, Sedum plumbizincicola, Triticum aestivum, and Zea mays under 
either salinity or metal stress condition [8-13], so far no attempt has been made to explore PBB and AMF interactions and their role in phytoremediation of metal-polluted saline soils. This has prompted us to explore the possibilities of enhancing the plant biomass and their metal uptake potential in metal-polluted saline soils using PBB and AMF as plant beneficial bioinoculants.

The objectives of this research were: i) to evaluate the interactive effects of PBB and AMF on plant growth, and ii) to assess the impacts of PBB and AMF on uptake and translocation of ions ( $\mathrm{Ni}$ and $\mathrm{Na}^{+}$) and biochemical parameters (chlorophyll and proline contents, lipid peroxidation, and electrolyte leakage) of $H$. annuus, in the presence and absence of abiotic stresses (HM and salinity either alone, or in combination).

\section{Materials and methods}

\subsection{Microorganisms and plant}

Pseudomonas libanensis TR1 (GenBank accession no. KR051238) was previously isolated from the rhizosphere of Trifolium repens grown in serpentine soils in Bragança, northeast of Portugal [3]. The morphological and physiological characteristics of $P$. libanensis TR1 were examined according to Mishra et al. [14]. Bacterial 1-aminocyclopropane1-carboxylate deaminase (ACCD) activity was determined according to Honma and Shimomura [15]. IAA synthesized by the strain was determined using Luria-Bertani (LB) medium amended with $0.5 \mathrm{mg} \mathrm{mL}^{-1}$ of L-tryptophan as described by Bric et al. [16]. Bacterial siderophore production was detected by chrome azurol S (CAS) agar plate assay [17]. Bacterial P solubilizing activity was quantitatively analyzed in the modified Pikovskayas medium [18] as described by Park et al. [19]. Extracellular polymeric substance (EPS) production [20], N fixation [21] and oxalate metabolism [22] were also analyzed.

The AMF Claroideoglomus claroideum BEG210 (formerly Glomus claroideum BEG210) originally isolated from saline sediment [23] was grown for 8 months in a multispore pot culture containing a 1:1 (v/v) mixture of zeolite and expanded clay with host plant $Z$. mays.

$H$. annuus was chosen for this study due to its capability of producing substantial biomass in a short period of time and accumulating considerable amounts of HM in its tissues [24].

\subsection{Effects of $\mathrm{NaCl}$ on bacterial growth}

Culture flasks ( $250 \mathrm{~mL}$ ) containing $20 \mathrm{~mL}$ LB amended with $0,3,6$ and $9 \%(\mathrm{w} / \mathrm{v})$ of $\mathrm{NaCl}$, were inoculated with logarithmic-phase bacterial strain. All the cultures including controls (in five replicates) were incubated at $28{ }^{\circ} \mathrm{C}$ for $168 \mathrm{~h}$ at $200 \mathrm{rpm}$. Bacterial growth was monitored by measuring the optical density (OD) at $600 \mathrm{~nm}$ on a spectrophotometer and counting colony forming units (CFU) at 8, 16, 24, 32, 73,120 , and $168 \mathrm{~h}$.

\subsection{Microcosm experiment setup}

The soil ( $\mathrm{pH}$ 7.4) was obtained from the Botanical Garden of the University of Coimbra, Portugal and its composition was $1.6 \%$ organic matter, $62.8 \mathrm{mg} \mathrm{kg}^{-1}$ available $\mathrm{N}, \quad 18.2 \mathrm{mg} \mathrm{kg}^{-1}$ available $\mathrm{P}$, $70.5 \mathrm{mg} \mathrm{kg}^{-1}$ available $\mathrm{K}, 1.5 \mathrm{meq}(100 \mathrm{~g})^{-1}$ cation exchange capacity and $0.3 \mathrm{dS} \mathrm{m}^{-1}$ electrical conductivity. The soil was dried, ground and sieved $(2 \mathrm{~mm})$, then sterilized by steaming $\left(100^{\circ} \mathrm{C}\right.$ for $1 \mathrm{~h}$ on 3 consecutive days). After sterilization, the soil was supplemented with aqueous $\mathrm{NiCl}_{2}$ solution to accomplish the final $\mathrm{Ni}$ concentration of $450 \mathrm{mg} \mathrm{kg}^{-1}$ and kept for 2 weeks in a greenhouse for metal stabilization.

The pots containing $1 \mathrm{~kg}$ of sterile soil were arranged in a $4 \times 2 \times 2$ factorial in a completely randomized block design involved four microbial treatments: i) blank; ii) PBB P. libanensis; iii) C. claroideum; v) PBB + AMF; two salt stress treatments: i) control (no stress); ii) salt stress (SS); and two metal stress treatments: i) control (no stress); ii) metal stress (MS).

Seeds of $H$. annuus were surface sterilized using $50 \%$ commercial bleach for $15 \mathrm{~min}$. and rinsed with sterile distilled water. Surface sterilized seeds were soaked for $2 \mathrm{~h}$ in the suspensions of strain TR1 $\left(\mathrm{OD}_{600}\right.$ of 1) marked with antibiotic resistance $\left(400 \mathrm{mg} \mathrm{L}^{-1}\right)$ or sterile water (non-PBB treatment) [3]. A thin layer of mycorrhizal inoculum (approximately $30 \mathrm{~g}$ ) was placed $3 \mathrm{~cm}$ below the soil before sowing to produce mycorrhizal plants. The non-AMF treatment received an equal amount of sterilized inoculum. Two concentrations $\left(0\right.$ and $4.6 \mathrm{~g} \mathrm{~kg}^{-1}$ soil) of saline solution were applied to initiate SS. To avoid osmotic shock, the $\mathrm{NaCl}$ concentration in the soil was gradually increased for 6 consecutive days until the desired concentration was achieved. A saucer was placed underneath each pot to collect excess water that was reapplied for irrigating the plants. Plants (two plants pot ${ }^{-1}$ ) were grown in a greenhouse at $25{ }^{\circ} \mathrm{C}$ with a $16 / 8$-h day/night regime for two months. Each treatment was carried out in five replicates.

\subsection{Parameters measured}

\subsubsection{Microbial colonization}

The survival rate of introduced strain TR1 in the rhizosphere was determined using the antibiotic marker combined with the dilutionplate method [25]. About $0.5 \mathrm{~g}$ root-adhering soil was shaken with $10 \mathrm{~mL}$ Ringer solution for $30 \mathrm{~min}$. The resulting suspensions were evaluated for $\mathrm{CFU}$ on $\mathrm{LB}$ agar containing $400 \mathrm{mg} \mathrm{L}^{-1}$ of chloramphenicol [3]. After incubation for $5 \mathrm{~d}$ at $28^{\circ} \mathrm{C}$, the re-isolated, chloramphenicol and abiotic stress $\left(500 \mathrm{mg} \mathrm{L}^{-1} \mathrm{Ni}\right.$ and $8 \% \mathrm{NaCl}$ [3]) resistant strains were identified for colony morphology, biochemical characteristics against the parent strains.

In order to quantify the percentage root length colonized (RLC) by $\mathrm{AMF}$, fine root samples were washed, cut into $1-\mathrm{cm}$ pieces and stained with trypan blue as described by Phillips and Hayman [26] and Oliveira et al. [27]. RLC was estimated with the gridline intersect method [28] under a stereomicroscope (Leica EZ4 HD, Germany).

\subsubsection{Biomass production}

At harvest (two months after planting), the shoot and root system were separated and plant fresh weight was measured immediately and dry weight after $48 \mathrm{~h}$ at $85^{\circ} \mathrm{C}$. After collecting root-adhering soil (for analysis of bacterial colonization), the roots were thoroughly washed with tap water and rinsed three times with deionized water to remove adhering soil. Fresh leaves were separated in $2 \mathrm{~g}$ aliquots and frozen in liquid $\mathrm{N}$ until the determination of proline content and lipid peroxidation. The salt tolerance index (STI), metal tolerance index (MTI), and salt and metal combined tolerance index (SMTI) were calculated using the following formulas [29,30]:

Salt tolerance index $(\%)=$ Plant biomass under salt stress / Plant biomass under no stress $\times 100$

Metal tolerance index (\%) = Plant biomass under metal stress / Plant biomass under no stress $\times 100$

Salt and metal combined tolerance index $(\%)=$ Plant biomass under salt and metal combined stresses / Plant biomass under no stress $\times 100$

\subsubsection{Chlorophyll content}

About $0.5 \mathrm{~g}$ of the leaf material was homogenized in chilled $100 \%$ $\mathrm{N}, \mathrm{N}$-dimethylformamide with a mortar and pestle and stored in darkness at $4{ }^{\circ} \mathrm{C}$ for $16 \mathrm{~h}$. The contents $\left(\mu \mathrm{g} \mathrm{mL} \mathrm{m}^{-1}\right.$ ) of Chlorophyll $a$, Chlorophyll $b$ and Chlorophyll $a+b$ were determined after the colorimetric method and the equation described by Lichtenthaler and Wellburn [31]. 


\subsubsection{Lipid peroxidation}

The malondialdehyde (MDA) content, as an index of lipid peroxidation in $H$. annuus leaves, was determined by reaction with thiobarbituric acid reactive substances in glacial acetic acid medium according to Giannakoula et al. [32].

\subsubsection{Proline content}

Proline accumulation was estimated by spectrophotometric analysis at $520 \mathrm{~nm}$ after ninhydrin reaction under acidic condition using toluene as a blank, according to Bates et al. [33]. Purified proline was used for standardization $\left(0-50 \mathrm{mg} \mathrm{mL}^{-1}\right)$ and expressed as $\mu \mathrm{mol} \mathrm{g}^{-1}$ fresh weight.

\subsubsection{Electrolyte leakage}

Electrolyte leakage (EL) from leaves was determined as described in Campos et al. [34]. Briefly, 15 fresh leaf discs (approximately $0.5 \mathrm{~cm}^{2}$ ) were placed in a boiling tube containing $10 \mathrm{~mL}$ deionized water and the initial electrical conductivity in the solution $\left(\mathrm{L}_{\mathrm{i}}\right)$ was measured after $24 \mathrm{~h}$ at $25^{\circ} \mathrm{C}$. The contents were then autoclaved at $120^{\circ} \mathrm{C}$ for $20 \mathrm{~min}$ and the final electrical conductivity $\left(\mathrm{L}_{\mathrm{f}}\right)$ was recorded after cooling. Results were expressed as the percentage of the initial conductivity versus the total conductivity. The EL (\%) was defined as follows: $\left(L_{i}-\right.$ $\left.\mathrm{L}_{\text {water }}\right) /\left(\mathrm{L}_{\mathrm{f}}-\mathrm{L}_{\mathrm{water}}\right) \times 100$, where $\mathrm{L}_{\mathrm{water}}$ was the conductivity of deionized water used to incubate the samples.

\subsubsection{Determination of metal and mineral}

The concentrations of $\mathrm{Ni}$ and $\mathrm{Na}^{+}$in plant tissues were measured using a flame atomic absorption spectrophotometer (PerkinElmer model 100, Massachusetts, USA) after digestion of $0.5 \mathrm{~g}$ of dried plant samples in a mixture of concentrated $\mathrm{HNO}_{3}$ and $\mathrm{HClO}_{4}(4: 1, \mathrm{v} / \mathrm{v})$ [35]. Translocation factor (TF) was calculated as metal concentration ratio of plant shoots to roots ([Metal] shoot / [Metal] root) [36].

\subsection{Statistical analysis}

The normality and homogeneity of variances of the data were verified. The $H$. annuus growth physiological and biochemical data were analyzed using three-way analysis of variance (ANOVA) for each dependent variable versus the independent variables [microbial inoculants (MI), SS and MS]. ANOVA followed by Tukey's Honestly Significant Difference (HSD) test $(p<0.05)$ was used to compare treatment means. All the statistical analyses were carried out using SPSS 19.0

\section{Results}

\subsection{Biochemical properties of Pseudomonas libanensis TR1}

$P$. libanensis exhibited high resistance against salinity (8\%) and extreme temperature $\left(4-38^{\circ} \mathrm{C}\right)$. Strain TR1 was gram-negative, motile, non-spore-forming rod shaped and positive for oxidase and catalase. It was able to produce indole, $\mathrm{H}_{2} \mathrm{~S}$, utilize L-arabinose, D-mannitol, malonate, and citrate as well as hydrolyze L-tyrosine and urea. Moreover, strain TR1 was a good ACCD, IAA, siderophore and EPS producer (Table 1).

\subsection{Bacterial growth under salt stress}

$P$. libanensis had great potential to grow in LB medium amended with increasing concentrations of $\mathrm{NaCl}(0,3,6$ and 9\%) (Fig. 1). The bacterial growth rates varied between control and three concentrations of $\mathrm{NaCl}$. During the initial $24 \mathrm{~h}$, the maximum growth was observed in control treatment, followed by that primed with $\mathrm{NaCl}$ (3 and 6\%). The higher $\mathrm{NaCl}$ concentration (9\%) considerably impaired bacterial growth rate compared to control and $\mathrm{NaCl}$ (3 and 6\%). However, after $24 \mathrm{~h}$ of incubation, strain TR1 maintained its prolonged survival to
Table 1

Morphological, physiological and biochemical characteristics of Pseudomonas libanensis TR1.

\begin{tabular}{|c|c|}
\hline Characteristic & Pseudomonas libanensis TR1 \\
\hline Gram staining & - \\
\hline Fluorescence & + \\
\hline Cell shape & Non-spore-forming rod \\
\hline Oxygen Requirements & Aerobic \\
\hline Motility & + \\
\hline Growth at $4-38^{\circ} \mathrm{C}$ & + \\
\hline Growth at $8 \% \mathrm{NaCl}$ & + \\
\hline Oxidase & + \\
\hline Catalase & + \\
\hline Indole production & + \\
\hline Voges-Proskauer test & - \\
\hline $\mathrm{H}_{2} \mathrm{~S}$ production & + \\
\hline Nitrate reduction & + \\
\hline Nitrite reduction & - \\
\hline \multicolumn{2}{|l|}{ Utilization of } \\
\hline L-arabinose & + \\
\hline D-mannitol & + \\
\hline Maltose & - \\
\hline Malonate & + \\
\hline Citrate & + \\
\hline Lactate & - \\
\hline \multicolumn{2}{|l|}{ Hydrolysis of } \\
\hline L-tyrosine & + \\
\hline Urea & + \\
\hline Gelatin & - \\
\hline Esculin & - \\
\hline $\begin{array}{l}\text { ACC deaminase production ( } \mu \mathrm{m} \alpha-\mathrm{KB} \mathrm{mg}^{-1} \mathrm{~h}^{-1} \\
\text { protein) }\end{array}$ & $34.2 \pm 6.7$ \\
\hline P solubilization $\left(\mathrm{mg} \mathrm{L}^{-1}\right)$ & - \\
\hline IAA production $\left(\mathrm{mg} \mathrm{L}^{-1}\right)$ & $88.2 \pm 5.6$ \\
\hline Siderophore production (CAS: mm) & $1.0 \pm 0.1$ \\
\hline EPS production & + \\
\hline Nitrogen fixation & + \\
\hline HCN production & - \\
\hline Oxalate metabolism & - \\
\hline
\end{tabular}

ACC, 1-aminocyclopropane-1-carboxylate; $\alpha$-KB, $\alpha$-ketobutyrate; P, phosphate; IAA, indole-3-acetic acid; CAS, chrome azurol S; EPS, extracellular polymeric substances; HCN, hydrogen cyanide; +, positive; -, negative.

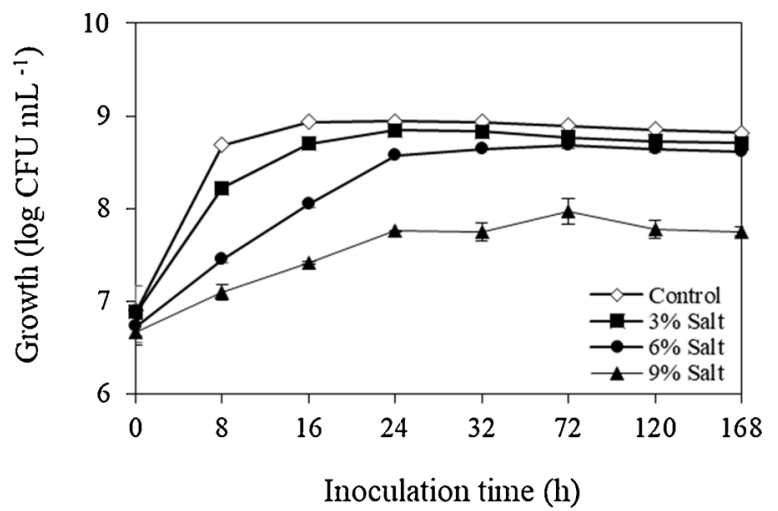

Fig. 1. Growth pattern of Pseudomonas libanensis in medium supplemented with increasing $\mathrm{NaCl}$ concentration. Bars represent SD of five replicates.

similar cell densities between control and $\mathrm{NaCl}$ (3 and 6\%).

\subsection{Microbial colonization}

In spite of SS and MS, $P$. libanensis displayed colonization potential in the rhizosphere of $H$. annuus after two months of inoculation (Fig. 1). Although strain TR1 exhibited high resistance to SS (Fig. 1) and MS (Table 1), such stresses (alone and in combination) significantly reduced bacterial colonization in the rhizosphere of $H$. annuus inoculated with $\mathrm{PBB}$ and $\mathrm{PBB}+\mathrm{AMF}$, except that SS had no influence on bacterial 

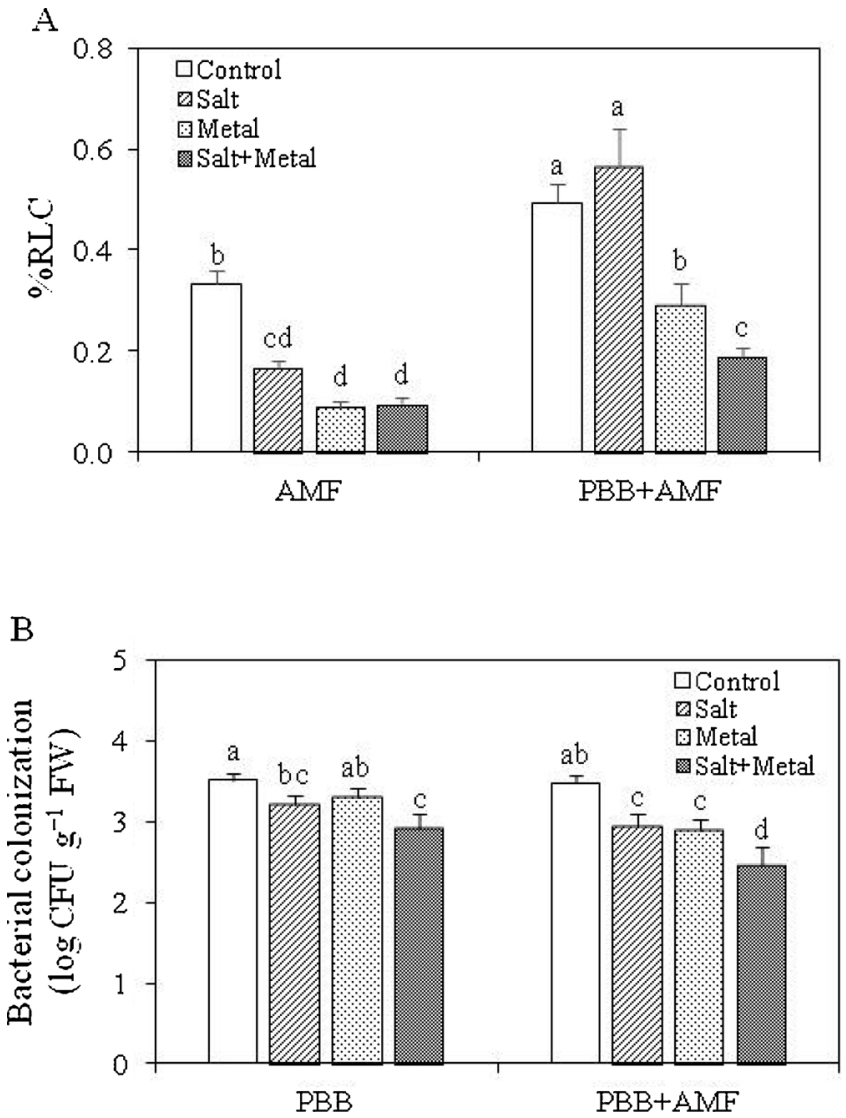

Fig. 2. Percentage root length colonized (\%RLC) by arbuscular mycorrhizal fungi (A) in the roots and bacterial colonization (B) in the rhizosphere of Helianthus annuus exposed to salinity and nickel stress. Bars represent SD of five replicates. Data of columns indexed by the same letter are not significantly different between microbial treatments according to Tukey's HSD test $(p<0.05)$.

colonization in the absence of AMF (Fig. 2). Moreover, co-inoculation of PBB and AMF caused a declination in the bacterial population across all stress conditions compared to inoculation of PBB alone, except for plants exposed to SS.

C. claroideum was able to colonize the roots of $H$. annuus, irrespective of SS, MS and SS + MS. However, in the absence of PBB, SS and MS (alone and in combination) greatly decreased percent root length colonized (\%RLC) by AMF. When $H$. annuus was co-inoculated with AMF and $\mathrm{PBB}$, SS did not influence \%RLC compared to their respective control treatments. Besides, MS and SS + MS significantly inhibited AMF colonization. There was no AMF colonization in non-inoculated plant roots.

\subsection{Plant growth and physiological parameters}

Non-inoculated plants exhibited a considerable decrease in fresh weight by 36,45 and $58 \%$ under SS, MS and SS + MS, respectively. The overall impact of combined stresses (SS + MS) on plant growth was additive and resulted in aggravated stress effects. Likewise, SS + MS greatly declined plant dry weight by $69 \%$, whereas SS or MS alone did not significantly influence plant biomass. Inoculation of microbes (PBB, $\mathrm{AMF}$ and $\mathrm{PBB}+\mathrm{AMF}$ ) significantly enhanced the fresh and dry weight of $H$. annuus grown under SS, MS and SS + MS (Table 2). For instance, under SS + MS the increase in plant fresh weight was $89 \%$ for PBB, $70 \%$ for AMF and $77 \%$ for PBB + AMF combination; for dry weight, the increase was 373,277 and $310 \%$, respectively. There were no significant differences in root/shoot dry weight ratio between control and stress treatments (SS, MS, and SS + MS) regardless of microbial inoculation, except that it was considerably enhanced by co-inoculation of $\mathrm{PBB}+\mathrm{AMF}$ under SS + MS. Moreover, inoculation of $P$. libanensis and C. claroideum alone and in combination led to higher STI or MTI of $H$. annuus grown under respective stress. However, no significant differences were observed in SMTI between control and inoculated plants grown under SS + MS.

EL was estimated to evaluate the degree of cell membrane injury induced by SS and MS. The results showed that non-inoculated plants exposed to SS, MS or SS + MS displayed an increase in EL in their leaves. The maximum increase in EL was observed in plants grown under SS and SS + MS (Fig. 3). There were no differences in EL between non-inoculated and AMF-treated plants. Nevertheless, inoculation with $\mathrm{PBB}$ or PBB + AMF resulted in a considerable decrease in EL of plants grown under SS, MS and SS + MS.

Leaf chlorophyll content was determined to examine the combined effects of MI, SS, and MS on the photosynthetic potential of $H$. annuus. In the absence of PBB and AMF, SS or MS alone did not influence Chl $a$, $\mathrm{Chl} b$, Chl $a+b$ and Chl $a / b$ ratio contents, but significantly decreased carotenoids (Table 3). However, plants grown under SS + MS showed reduced $\mathrm{Chl} a$, Chl $a+b$ and carotenoids compared to non-stressed controls. The PBB inoculation significantly increased the contents of leaf Chl $b$, Chl $a+b$ and carotenoids in plants under SS by 123,45 , $67 \%$, respectively, while there was a reduction in $\mathrm{Chl} a / b$ ratio of $55 \%$ compared with the corresponding non-inoculated plants. AMF and $\mathrm{PBB}+\mathrm{AMF}$ greatly improved contents of Chl $a+b$ in plants under SS and Chl $a$ in plants under SS + MS, compared to their respective noninoculated controls.

\subsection{Biochemical parameters}

Proline and MDA accumulation in plant cells were determined to examine the adaptive response of host plants to SS and MS. Non-inoculated plants grown under SS, MS or SS + MS exhibited a substantial increase in proline contents. The utmost increase was observed in plants exposed to SS + MS (Fig. 4). However, in the presence of SS, MS and $\mathrm{SS}+\mathrm{MS}$, inoculation with $\mathrm{PBB}$ and $\mathrm{PBB}+\mathrm{AMF}$ considerably reduced proline contents in $H$. annuus leaves. MDA content in leaves of noninoculated plants grown under SS, MS and SS + MS was remarkably higher than that detected in non-stressed control; however, inoculation with PBB greatly diminished oxidative stress (Fig. 4). For instance, $P$. libanensis decreased MDA content in leaves of plants exposed to SS, MS and SS + MS by 29,49 and $51 \%$, respectively. There were no differences in MDA contents between AMF inoculated and non-inoculated plants, except under SS, where MDA contents in AMF inoculated plants were significantly lower than the corresponding non-inoculated control. The co-inoculation of $\mathrm{PBB}$ and AMF resulted in a declination in MDA contents when plants were exposed to MS and SS + MS.

The effects of microbial inoculation on the accumulation of $\mathrm{Ni}$ and $\mathrm{Na}^{+}$by $\mathrm{H}$. annuus were evaluated (Fig. 5). Ni was not detected in plants grown in garden soils. However, in the case of MS, inoculation of PBB, $\mathrm{AMF}$ and $\mathrm{PBB}+\mathrm{AMF}$ significantly increased Ni accumulation in plants by 82,38 , and $45 \%$, respectively, compared with non-inoculated control. This is inconsistent with the microbial induced reduction in TF of Ni. For instance, inoculation of PBB, AMF and PBB + AMF significantly decreased TF of Ni by 67,50 and $67 \%$ respectively, compared with noninoculated controls. Concentrations of $\mathrm{Ni}$ increased considerably $(p<0.05)$, when non-inoculated plants were exposed to MS + SS. However, inoculation of $\mathrm{PBB}, \mathrm{AMF}$ and $\mathrm{PBB}+\mathrm{AMF}$ significantly declined plant $\mathrm{Ni}$ accumulation under MS + SS by 34,28 and $40 \%$, respectively, compared to the corresponding non-inoculated controls. Nevertheless, the inoculation of PBB alone greatly enhanced TF of $\mathrm{Ni}$ $(p<0.05)$.

$\mathrm{Na}^{+}$concentrations in non-inoculated plants under control or MS were significantly lower than those detected in plants grown under SS or SS + MS treatments (Fig. 5). Inoculation of PBB and PBB + AMF greatly reduced $\mathrm{Na}^{+}$accumulation in plants grown under SS and 
Table 2

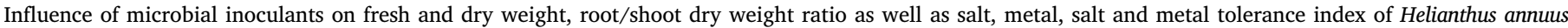
exposed to salinity and nickel stress.

\begin{tabular}{|c|c|c|c|c|c|c|c|}
\hline Treatment & & $\begin{array}{l}\text { Fresh weight } \\
\text { (mg plant }^{-1} \text { ) }\end{array}$ & $\begin{array}{l}\text { Dry weight } \\
\text { (mg plant }^{-1} \text { ) }\end{array}$ & $\begin{array}{l}\text { Root/shoot dry weight } \\
\text { ratio }\end{array}$ & $\begin{array}{l}\text { Salt tolerance } \\
\text { index } \\
\%\end{array}$ & $\begin{array}{l}\text { Metal tolerance } \\
\text { index } \\
\%\end{array}$ & $\begin{array}{l}\text { Salt and metal combined } \\
\text { tolerance index } \\
\%\end{array}$ \\
\hline \multirow[t]{4}{*}{ Control } & Blank & $11.2 \pm 0.5 \mathrm{bcd}$ & $0.96 \pm 0.08 \mathrm{bcd}$ & $0.07 \pm 0.03 \mathrm{bc}$ & - & - & - \\
\hline & PBB & $16.4 \pm 1.0 \mathrm{a}$ & $1.31 \pm 0.18 \mathrm{ab}$ & $0.05 \pm 0.02 \mathrm{~b}$ & - & - & - \\
\hline & AMF & $12.7 \pm 0.7 \mathrm{bc}$ & $0.97 \pm 0.29 \mathrm{bcd}$ & $0.10 \pm 0.02 b c$ & - & - & - \\
\hline & $\mathrm{PBB}+\mathrm{AMF}$ & $13.6 \pm 1.4 \mathrm{~b}$ & $1.20 \pm 0.31 \mathrm{ab}$ & $0.07 \pm 0.02 b c$ & - & - & - \\
\hline \multirow[t]{4}{*}{ Salt stress } & Blank & $7.2 \pm 0.6 \mathrm{gh}$ & $0.67 \pm 0.01 \mathrm{de}$ & $0.06 \pm 0.01 \mathrm{~b}$ & $54.6 \pm 7.9 b$ & - & - \\
\hline & PBB & $12.1 \pm 0.9 \mathrm{bc}$ & $1.59 \pm 0.26 \mathrm{a}$ & $0.05 \pm 0.01 \mathrm{~b}$ & $73.9 \pm 9.1 \mathrm{a}$ & - & - \\
\hline & $\mathrm{AMF}$ & $10.7 \pm 0.7 \mathrm{cde}$ & $1.64 \pm 0.40 \mathrm{a}$ & $0.10 \pm 0.02 b c$ & $84.5 \pm 4.3 \mathrm{a}$ & - & - \\
\hline & $\mathrm{PBB}+\mathrm{AMF}$ & $11.6 \pm 1.5 \mathrm{bcd}$ & $1.23 \pm 0.46 \mathrm{ab}$ & $0.08 \pm 0.02 b c$ & $85.9 \pm 10.2 \mathrm{a}$ & - & - \\
\hline \multirow[t]{4}{*}{ Metal stress } & Blank & $6.2 \pm 0.8 \mathrm{gh}$ & $0.54 \pm 0.05 \mathrm{cde}$ & $0.10 \pm 0.04 \mathrm{bc}$ & - & $55.3 \pm 9.5 \mathrm{c}$ & - \\
\hline & PBB & $12.1 \pm 1.2 \mathrm{bc}$ & $1.50 \pm 0.25 \mathrm{ab}$ & $0.07 \pm 0.02 b c$ & - & $73.6 \pm 5.8 \mathrm{ab}$ & - \\
\hline & $\mathrm{AMF}$ & $8.4 \pm 0.7$ efg & $\begin{array}{l}1.05 \pm 0.13 \\
\text { abcd }\end{array}$ & $0.12 \pm 0.03 \mathrm{bc}$ & - & $65.9 \pm 4.2 \mathrm{bc}$ & - \\
\hline & $\mathrm{PBB}+\mathrm{AMF}$ & $11.2 \pm 1.3 \mathrm{bcd}$ & $1.42 \pm 0.25 \mathrm{ab}$ & $0.09 \pm 0.02 \mathrm{bc}$ & - & $82.7 \pm 10.4 \mathrm{a}$ & - \\
\hline \multirow[t]{4}{*}{ Salt + metal stresses } & Blank & $4.7 \pm 0.1 \mathrm{~h}$ & $0.30 \pm 0.05 \mathrm{e}$ & $0.15 \pm 0.02 \mathrm{~b}$ & - & - & $41.0 \pm 0.7 \mathrm{a}$ \\
\hline & PBB & $8.9 \pm 0.9 \mathrm{def}$ & $1.42 \pm 0.23 \mathrm{ab}$ & $0.08 \pm 0.03 \mathrm{bc}$ & - & - & $53.9 \pm 3.6 \mathrm{a}$ \\
\hline & AMF & $8.0 \pm 1.5 \mathrm{fg}$ & $1.13 \pm 0.11 \mathrm{abc}$ & $0.12 \pm 0.02 \mathrm{bc}$ & - & - & $62.9 \pm 13.2 \mathrm{a}$ \\
\hline & $\mathrm{PBB}+\mathrm{AMF}$ & $8.3 \pm 1.2 \mathrm{efg}$ & $1.23 \pm 0.09 \mathrm{ab}$ & $0.42 \pm 0.10 \mathrm{a}$ & - & - & $61.3 \pm 10.8 \mathrm{a}$ \\
\hline \multicolumn{2}{|c|}{ Microbial inoculants (MI) } & $F=72.9 * * *$ & $F=39.6 * * *$ & $F=28.8^{* * *}$ & - & - & - \\
\hline \multicolumn{2}{|c|}{ Salt stress (SS) } & $F=100.5 * * *$ & $F=0.0 \mathrm{~ns}$ & $F=34.7 * * *$ & - & - & - \\
\hline \multicolumn{2}{|l|}{ Metal stress (MS) } & $F=158.4 * * *$ & $F=2.8 \mathrm{~ns}$ & $F=75.7 * * *$ & - & - & - \\
\hline \multicolumn{2}{|l|}{ MI x SS } & $F=4.6 * *$ & $F=6.5 * *$ & $F=23.9 * * *$ & - & - & - \\
\hline \multicolumn{2}{|l|}{ MI x MS } & $F=0.5 \mathrm{~ns}$ & $F=2.5 \mathrm{~ns}$ & $F=20.1 * * *$ & - & - & - \\
\hline \multicolumn{2}{|l|}{ SS $\mathrm{x}$ MS } & $F=6.6 *$ & $F=3.9 \mathrm{~ns}$ & $F=36.5 * * *$ & - & - & - \\
\hline \multicolumn{2}{|l|}{ MI x SS x MS } & $\mathrm{F}=3.0 *$ & $F=2.1 \mathrm{~ns}$ & $F=20.7 * * *$ & - & - & - \\
\hline
\end{tabular}

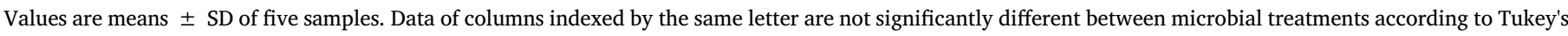

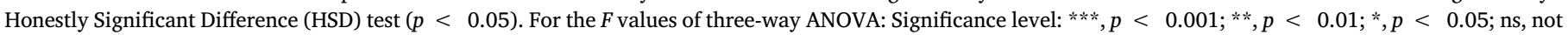
significant.

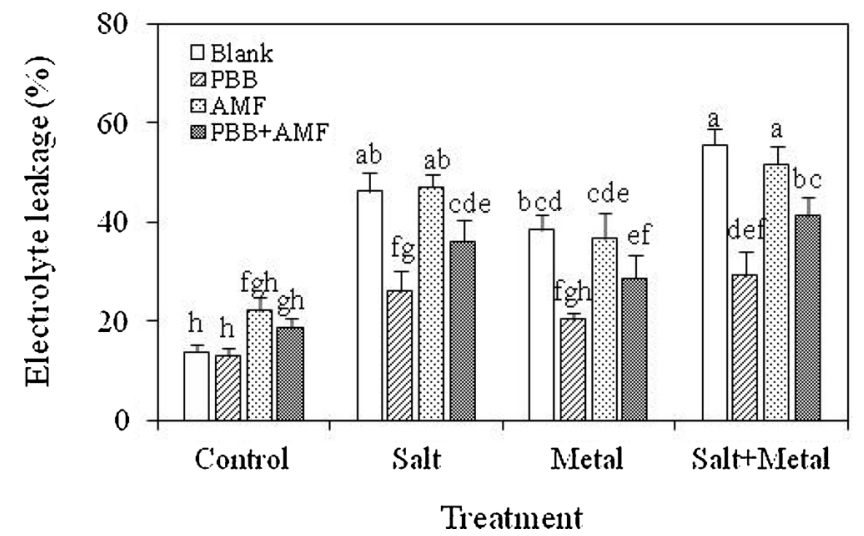

Fig. 3. Effects of microbial inoculation on electrolyte leakage in Helianthus annuus exposed to salinity and nickel stress. Bars represent SD of five replicates. Statistical notation is the same as in Fig. 2.

SS + MS compared with respective non-inoculated controls. No differences in $\mathrm{Na}^{+}$accumulation were detected between non-inoculated controls and inoculated ( $\mathrm{PBB}, \mathrm{AMF}$ and $\mathrm{PBB}+\mathrm{AMF}$ ) plants grown under control or MS condition. In the case of SS + MS, inoculation of $\mathrm{PBB}, \mathrm{AMF}$ and PBB + AMF considerably increased TF of $\mathrm{Na}^{+}$by 44,56 and $44 \%$, respectively.

\section{Discussion}

Due to global climate change, the frequency and severity of plant abiotic stresses (such as salinity, drought, HM, and extreme temperatures) have been increasing [37]. Consequently, the efficiency of phytoremediation processes can be compromised, as the remediating plants are likely to encounter various environmental stresses under field conditions [3,4]. Among the environmental stresses, soil salinity can devastatingly affect plant growth and metabolism [38]. Salinity can provoke dual stress on plants, related not only with rapid osmotic stress instigated by a diminished water potential and weakened ability to take up water, but also with slow ion-dependent stress or ionic imbalance as a result of the toxic accumulation of $\mathrm{Na}^{+}$in plant tissues that perturbs nutrient uptake over time [1]. $\mathrm{Na}^{+}$accumulation in shoots can induce leaf senescence and impair photosynthetic activity, interfering in processes such as photosynthetic rate, competing for $\mathrm{K}^{+}$transport and enzymatic reactions. PGPM can improve plant growth, yield, and nutrient uptake through various mechanisms. Direct mechanisms may act on plants themselves and enhance their growth by means of plant growth regulators (e.g. production of phytohormones and siderophores), solubilization of mineral nutrients ( $\mathrm{P}, \mathrm{K}$, and iron) and fixation of atmospheric N [7]. Harnessing the potential of PGPM in the rhizosphere can be an alternative to enhance stress tolerance of plants and thus their remediation potential. Therefore, PGPM (PBB and AMF) were used in the present study for accelerating phytoremediation of metal-contaminated saline soils.

Both salt and metal stresses considerably hampered plant growth and induced physiological and biochemical changes in $H$. annuus. Combined SS and MS aggravated their individual effects on plant growth (Table 2). The similarity and superimposing effects of plants' responses to SS and MS demonstrated that the adverse effects of SS on plants exacerbated their response to MS. This could be due to salt-induced EL (Fig. 3). As a hallmark of stress response in intact plant cells, EL has been reported in different plant species, organs and cell types grown under salinity, heat, and drought stresses [39]. It has been widely described that $\mathrm{SS}$ induce $\mathrm{K}^{+}$efflux through displacement of cell membrane-associated $\mathrm{Ca}^{2+}$ by $\mathrm{Na}^{+}$from the root cell plasmalemma resulting in membrane permeability damage and higher EL [39]. In the present study, non-inoculated plants showed an increase in EL under SS, MS or SS + MS, whereas plants inoculated with PBB showed a significant decrease in EL under SS, MS, or SS + MS. These results concur with earlier observations indicating that $\mathrm{PBB}$ reduced the toxic effects of SS by decreasing EL through the production of phytohormones (IAA and CK) and improving membrane stability [40,41]. 
Table 3

Chlorophyll contents in leaves of Helianthus annuus exposed to salinity and nickel stress.

\begin{tabular}{|c|c|c|c|c|c|c|}
\hline Treatment & & $\begin{array}{l}\text { Chl } a \\
\left(\mathrm{mg} \mathrm{g}^{-1} \mathrm{FW}\right)\end{array}$ & $\begin{array}{l}\text { Chl } b \\
\left(\mathrm{mg} \mathrm{g}^{-1} \mathrm{FW}\right)\end{array}$ & $\begin{array}{l}\text { Chl } a+b \\
\left(\mathrm{mg} \mathrm{g}^{-1} \mathrm{FW}\right)\end{array}$ & Chl $a / b$ ratio & $\begin{array}{l}\text { Carotenoids } \\
\left(\mathrm{mg} \mathrm{g}^{-1} \mathrm{FW}\right)\end{array}$ \\
\hline \multirow[t]{4}{*}{ Control } & Blank & $2.7 \pm 0.1 b c$ & $2.1 \pm 0.2 \mathrm{abcd}$ & $4.9 \pm 0.2 \mathrm{abcd}$ & $1.3 \pm 0.1 \mathrm{abc}$ & $1.3 \pm 0.1 \mathrm{bcd}$ \\
\hline & PBB & $3.1 \pm 0.1 \mathrm{a}$ & $2.1 \pm 0.1 \mathrm{a}$ & $5.2 \pm 0.1 \mathrm{ab}$ & $1.5 \pm 0.1 \mathrm{abc}$ & $1.5 \pm 0.1 \mathrm{a}$ \\
\hline & AMF & $2.7 \pm 0.1 \mathrm{bcd}$ & $2.5 \pm 0.2 \mathrm{abc}$ & $5.2 \pm 0.2 \mathrm{ab}$ & $1.1 \pm 0.1 \mathrm{bc}$ & $1.1 \pm 0.1 \mathrm{cde}$ \\
\hline & $\mathrm{PBB}+\mathrm{AMF}$ & $2.9 \pm 0.1 \mathrm{ab}$ & $2.1 \pm 0.2 \mathrm{abcd}$ & $5.0 \pm 0.3 \mathrm{abc}$ & $1.4 \pm 0.2 \mathrm{abc}$ & $1.1 \pm 0.1 \mathrm{cde}$ \\
\hline \multirow[t]{4}{*}{ Salt stress } & Blank & $2.5 \pm 0.0 \mathrm{cde}$ & $1.3 \pm 0.3 \mathrm{~d}$ & $3.8 \pm 0.4 \mathrm{de}$ & $2.0 \pm 0.6 \mathrm{a}$ & $0.9 \pm 0.0 \mathrm{fg}$ \\
\hline & PBB & $2.6 \pm 0.2 \mathrm{~cd}$ & $2.9 \pm 0.7 \mathrm{a}$ & $5.5 \pm 0.6 \mathrm{a}$ & $0.9 \pm 0.2 \mathrm{bc}$ & $1.5 \pm 0.1 \mathrm{ab}$ \\
\hline & $\mathrm{AMF}$ & $2.6 \pm 0.1 \mathrm{bcd}$ & $2.3 \pm 0.4 \mathrm{abcd}$ & $5.0 \pm 0.5 a b c$ & $1.2 \pm 0.2 \mathrm{abc}$ & $1.2 \pm 0.1 \mathrm{~cd}$ \\
\hline & $\mathrm{PBB}+\mathrm{AMF}$ & $2.2 \pm 0.1 \mathrm{e}$ & $2.7 \pm 0.4 \mathrm{ab}$ & $5.0 \pm 0.5 a b c$ & $0.8 \pm 0.1 \mathrm{c}$ & $1.0 \pm 0.1 \mathrm{efg}$ \\
\hline \multirow[t]{4}{*}{ Metal stress } & Blank & $2.6 \pm 0.1 \mathrm{~cd}$ & $1.5 \pm 0.2 \mathrm{~cd}$ & $4.1 \pm 0.1 \mathrm{cde}$ & $1.7 \pm 0.3 \mathrm{abc}$ & $0.9 \pm 0.1 \mathrm{~g}$ \\
\hline & PBB & $2.6 \pm 0.3 \mathrm{~cd}$ & $2.3 \pm 0.2 \mathrm{abcd}$ & $4.9 \pm 0.3 \mathrm{abc}$ & $1.1 \pm 0.2 \mathrm{bc}$ & $1.2 \pm 0.1 \mathrm{cde}$ \\
\hline & AMF & $2.4 \pm 0.0 \mathrm{cde}$ & $1.8 \pm 0.6 \mathrm{bcd}$ & $4.3 \pm 0.6$ bcde & $1.5 \pm 0.7 \mathrm{abc}$ & $1.1 \pm 0.0 \mathrm{cde}$ \\
\hline & $\mathrm{PBB}+\mathrm{AMF}$ & $2.5 \pm 0.1 \mathrm{cde}$ & $2.1 \pm 0.2 \mathrm{abcd}$ & $4.6 \pm 0.3$ abcde & $1.2 \pm 0.2 \mathrm{abc}$ & $1.1 \pm 0.1 \mathrm{def}$ \\
\hline \multirow[t]{4}{*}{ Salt + metal stresses } & Blank & $1.9 \pm 0.2 \mathrm{f}$ & $1.8 \pm 0.4 \mathrm{bcd}$ & $3.7 \pm 0.3 \mathrm{e}$ & $1.2 \pm 0.4 \mathrm{abc}$ & $1.0 \pm 0.1 \mathrm{efg}$ \\
\hline & PBB & $2.4 \pm 0.0 \mathrm{de}$ & $2.0 \pm 0.4 \mathrm{abcd}$ & $4.4 \pm 0.4$ bcde & $1.3 \pm 0.3 \mathrm{abc}$ & $1.4 \pm 0.1 \mathrm{abc}$ \\
\hline & $\mathrm{AMF}$ & $2.5 \pm 0.1 \mathrm{cde}$ & $1.6 \pm 0.6 \mathrm{~cd}$ & $4.1 \pm 0.6 \mathrm{cde}$ & $1.8 \pm 0.7 \mathrm{ab}$ & $1.2 \pm 0.1 \mathrm{cde}$ \\
\hline & $\mathrm{PBB}+\mathrm{AMF}$ & $2.4 \pm 0.1 \mathrm{de}$ & $1.9 \pm 0.5 \mathrm{abcd}$ & $4.3 \pm 0.5$ bcde & $1.3 \pm 0.4 \mathrm{abc}$ & $1.1 \pm 0.1 \mathrm{def}$ \\
\hline Microbial inoculants (MI) & & $F=11.3 * * *$ & $F=7.1 * * *$ & $F=13.1 * * *$ & $F=3.5 *$ & $F=63.0 * * *$ \\
\hline Salt stress (SS) & & $F=90.0 * * *$ & $F=0.4 \mathrm{~ns}$ & $F=7.9^{* *}$ & $F=0.3 \mathrm{~ns}$ & $F=2.3 \mathrm{~ns}$ \\
\hline Metal stress (MS) & & $F=75.1 * * *$ & $F=12.9 * *$ & $F=41.2 * * *$ & $F=1.2 \mathrm{~ns}$ & $F=23.6^{* * *}$ \\
\hline MI x SS & & $F=12.1 * * *$ & $F=1.6 \mathrm{~ns}$ & $F=2.0 \mathrm{~ns}$ & $F=1.4 \mathrm{~ns}$ & $F=3.1 *$ \\
\hline MI x MS & & $F=2.8 *$ & $F=1.4 \mathrm{~ns}$ & $F=0.9 \mathrm{~ns}$ & $F=2.8 *$ & $F=8.2 * * *$ \\
\hline SS $\mathrm{x}$ MS & & $F=4.3 *$ & $F=1.9 \mathrm{~ns}$ & $F=0.4 \mathrm{~ns}$ & $F=0.1 \mathrm{~ns}$ & $F=23.6 * * *$ \\
\hline MI x SS x MS & & $\mathrm{F}=12.0 * * *$ & $F=6.0 * *$ & $F=2.2 \mathrm{~ns}$ & $F=6.8 * *$ & $F=8.6 * * *$ \\
\hline
\end{tabular}

See Table 2 for legend.

A

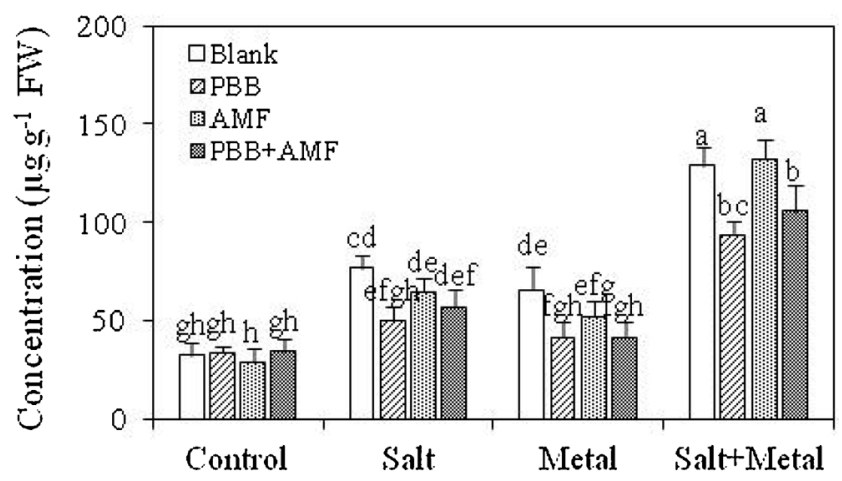

Treatment

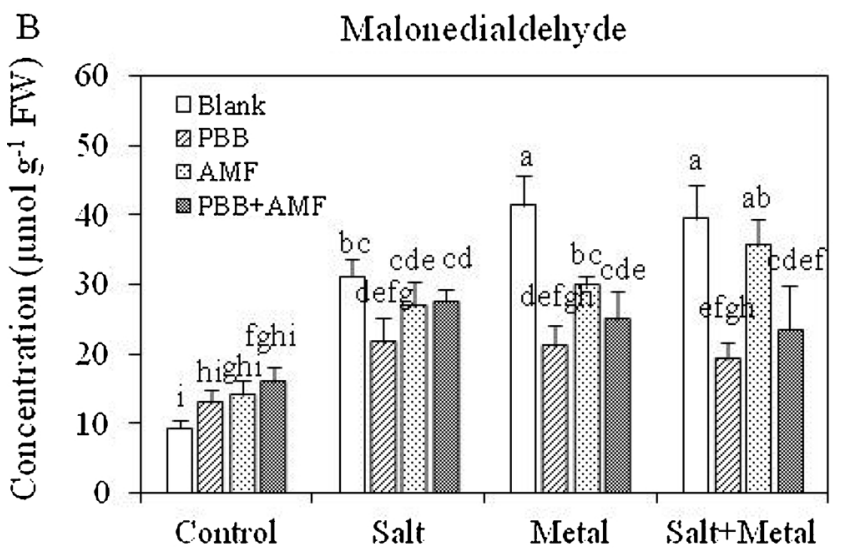

Treatment

Fig. 4. Effects of microbial inoculation on proline (A) and malondialdehyde concentration (B) in Helianthus annuus exposed to salinity and nickel stress. Bars represent SD of five replicates. Statistical notation is the same as in Fig. 2.
In addition, $\mathrm{PBB}$ and $\mathrm{AMF}$ reduce deleterious effects of abiotic stress in plants by increasing chlorophyll content [42]. In our study, the recorded values of $\mathrm{Chl} b$, Chl $a+b$ and carotenoid indicate that PBB inoculation maintained proper growth and survival of plants under SS. This may be linked with PBB mediated ACCD activity, which maintains the photosynthetic efficiency of plants by reducing ethylene biosynthesis [43]. Bal et al. [44] found that inoculation of ACCD-containing Alcaligenes sp. SB1.ACC2, Bacillus sp. SB1.ACC3 and Ochrobactrum sp. SB2.ACC2 decreased the toxic effects of salinity in plants by increasing chlorophyll content, consequently improving photosynthetic rate, growth and salt tolerance in Oryza sativa. Similarly higher chlorophyll content was also reported in ACCD-containing PBB that was inoculated in salt stressed Solanum lycopersicum [45] and Cucumis sativus [46], compared to ACCD-deficient mutant-inoculated or non-inoculated plants.

Proline accumulation is considered as one of the most common stress responses in plants, which protects cells and tissues against MS and SS. Under SS, plants accumulate several compatible solutes, particularly proline in the cell cytoplasm to maintain the osmotic potential of the accumulated salt in plant vacuole $[47,48]$ and to protect plants against oxidative stress through reactive oxygen species detoxification, cellular osmotic adjustment, membrane integrity maintenance and enzymes stabilization $[49,50]$. In the present study, non-inoculated plants grown under SS and/or MS accumulated more proline than plants inoculated with PGPM. The observation implies that PGPM treatment could counteract the effects of SS and MS through inducing the regulation of osmotic balance and maintaining the bioenergetics of the cell [51]. Similar effects of inoculation were also reported by Singh and Jha [52] who observed that the inoculation of T. aestivum with Stenotrophomonas maltophilia SBP-9 decreased the proline content in plants challenged with $150 \mathrm{mM}$ and $200 \mathrm{mM} \mathrm{NaCl}$ by 45.9 and $32.13 \%$, respectively. This study showed that the PGPM reduce the injury level in plants by producing plant-growth promoting metabolites (e.g. ACCD, gibberellic acid, IAA, siderophore, and inorganic P solubilization) and thus lower proline accumulation in plants. Similar results were found in Z. mays inoculated with AMF (Glomus etunicatum) and PBB (Methylobacterium oryzae) under SS [53].

Abiotic stress increases the oxidative damage to lipids, which increments MDA content and thus causes a rise in membrane 

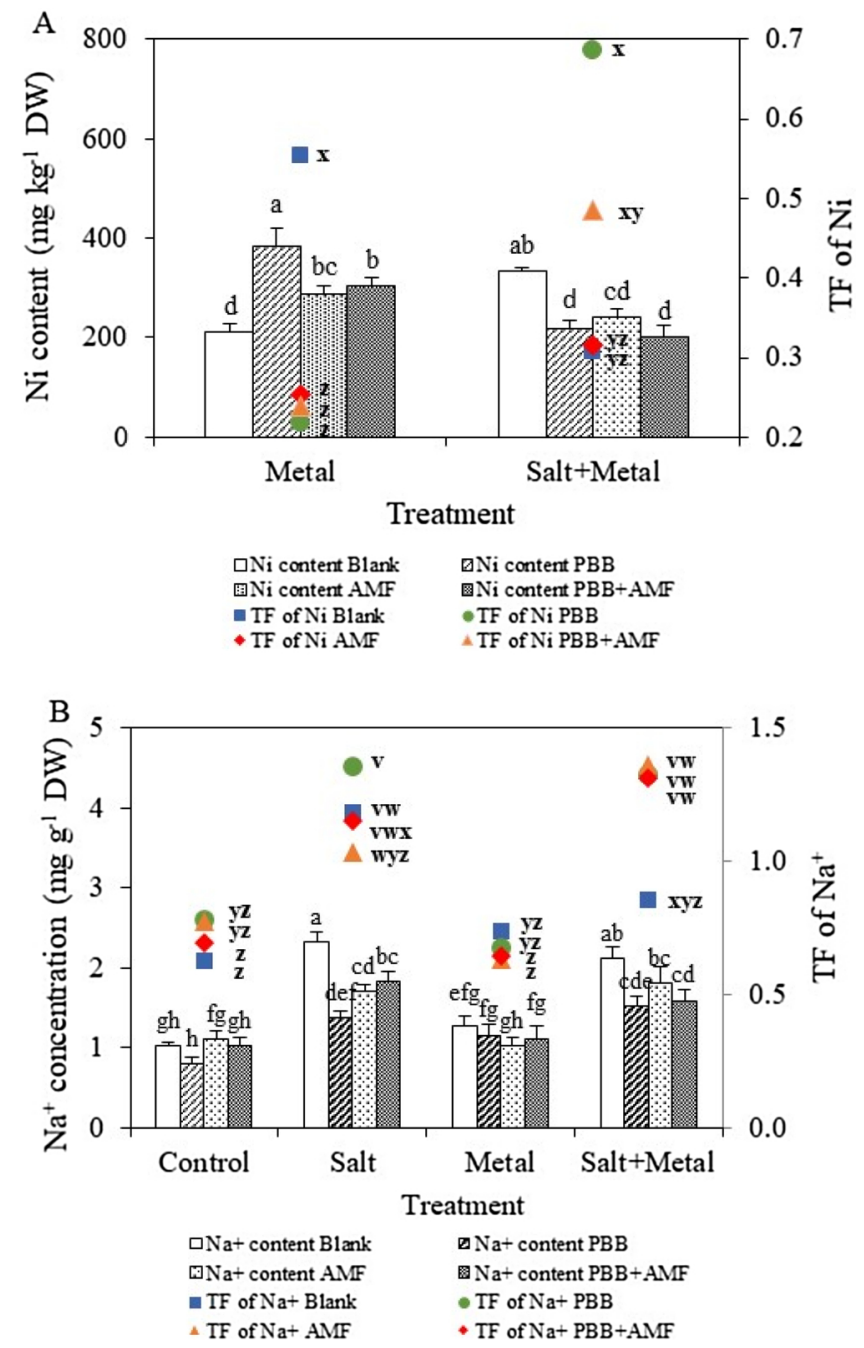

Fig. 5. Nickel (A) and sodium (B) uptake and translocation factor, and $\mathrm{NaCl}$ concentrations in Helianthus annuus exposed to salinity and nickel stress. Bars represent SD of five replicates. Statistical notation is the same as in Fig. 2.

permeability and cell injuries [54]. Therefore, oxidative damage due to SS and/or MS was determined by estimating the quantity of MDA in PGPM inoculated and non-inoculated plants. The MDA contents in noninoculated plants increased by 244, 356 and $333 \%$ under SS, MS and SS + MS respectively, while co-inoculation of $P$. libanensis and C. claroideum resulted in reduced membrane damage with 73,58 and $48 \%$ decreases, respectively in MDA contents as compared to non-inoculated control. The decrease in MDA content in PGPM inoculated plants indicates that microbial inoculation protected the plants by lowering cell injuries and increasing tolerance of host plants to SS and/or MS. Similar results were found in T. aestivum inoculated with Bacillus licheniformis HSW-16 under SS [55].

The efficiency of phytoremediation of pollutants varies according to plant biomass production, pollutant phytoavailability in the soil as well as formation and activities of microbial root symbioses [7]. In turn, rhizosphere colonization of PGPM can benefit plant growth and metal mobilization/stabilization, assisting phytoremediation in an eco-benign manner, as they have great potential to change the properties of rhizosphere soil ( $\mathrm{pH}$, water, salt, and nutrient contents), root exudates composition, and indigenous microbial activity and functions [3,7].

The effects of inoculation of PGPM on the accumulation of ions $\left(\mathrm{Ni}^{2+}\right.$ and $\left.\mathrm{Na}^{+}\right)$in $H$. annuus were determined under SS, MS, or SS + MS. Non-inoculated plants grown under SS + MS accumulated excessive $\mathrm{Ni}$ in tissues compared to those grown under MS. This can be attributed to SS-induced alteration in the rhizosphere properties including organic acid exudation by plant roots, decreasing rhizosphere soil $\mathrm{pH}$, and increasing metal bioavailability [56]. In contrast, Leblebici et al. [57] demonstrated that the accumulation of Cd and Ni in Spirodela polyrrhiza decreased with increase in salinity. They explained that the decreased metal uptake by $S$. polyrrhiza can be due to the great cation competition between $\mathrm{Ni}^{2+}$ and $\mathrm{Na}^{+}$. In the present study, inoculation of $\mathrm{PBB}, \mathrm{AMF}$ and $\mathrm{PBB}+\mathrm{AMF}$ significantly increased plant Ni uptake under MS, but Ni uptake was greatly reduced under SS + MS (Fig. 5). The results indicate that PGPM behaved differently in influencing plant Ni uptake under MS and SS + MS. When plants respond to MS, the inoculation of PGPM induced an increase in plant biomass and Ni uptake. This is probably attributed to the capacity of $\mathrm{PBB}$ to produce ACCD, IAA production, and siderophore. The decrease in Ni uptake under SS + MS was possibly due to the SS-mediated stimulation of the bacterial EPS production. It has been documented that EPS-producing PBB reduce plant metal uptake by complexing metals with EPS and decreasing their mobility in the soils [58]. In addition, the TF of Ni $(<1)$ was reduced by $\mathrm{PBB}, \mathrm{AMF}$ and $\mathrm{PBB}+\mathrm{AMF}$ under MS, but significantly enhanced by $\mathrm{PBB}$ and $\mathrm{PBB}+\mathrm{AMF}$ under SS + MS (Fig. 5), suggesting that the association of such microbes (PBB, AMF and $\mathrm{PBB}+\mathrm{AMF}$ ) with ( $H$. annuus is desirable for phytostabilization purposes. However, in the presence of multiple stresses (SS + MS), PBB mediated translocation of $\mathrm{Ni}$ into shoot tissues. Nevertheless, the accumulated Ni mainly remained in the root system [59]. This is in good agreement with Ma et al. [3], who found that Ni concentration was higher in roots than in shoots of $H$. annuus.

$\mathrm{NaCl}$ treatment induced a considerable increase in $\mathrm{Na}^{+}$concentrations in plants grown under SS and SS + MS compared to those grown under non-stressed control; however the inoculation with PBB, AMF and $\mathrm{PBB}+\mathrm{AMF}$ reduced the uptake of $\mathrm{Na}^{+}$under SS and SS + MS. A possible explanation could be that the capacity of $P$. libanensis to synthesize EPS (Table 1) that can strongly bind cations to the bacterial cell surfaces along with the enhancement of their population density in the rhizosphere, may reduce $\mathrm{Na}^{+}$concentration available for plant uptake [60]. Similarly, several studies have found that inoculation of EPSproducing PGPM resulted in lower $\mathrm{Na}^{+}$concentrations in the tissues of O. sativa, Z. mays and Fragaria ananassa grown under SS [39,61,62]. Regardless of microbial inoculation, the addition of Ni did not influence plant accumulation of $\mathrm{Na}^{+}$, indicating that MS did not exacerbate the transport and mobility of $\mathrm{Na}^{+}$in $H$. annuus. Under SS, the TF of $\mathrm{Na}^{+}$ was not influenced by either PBB or AMF inoculation. Nevertheless, inoculation of $\mathrm{PBB}, \mathrm{AMF}$ and $\mathrm{PBB}+\mathrm{AMF}$ significantly increased TF of $\mathrm{Na}^{+}$under SS + MS, highlighting that PGPM inoculations helped $\mathrm{Na}^{+}$ to be translocated into plant shoots. The increases in $\mathrm{TF}$ of $\mathrm{Na}^{+}$(Fig. 5) and biomass production (Table 2) under SS + MS might be attributed to the ability of PGPM to remove $\mathrm{Na}^{+}$from the transpiration stream and sequester $\mathrm{Na}^{+}$in shoots (particularly leaf vacuoles) [63]. Further investigations are necessary to study the role of PGPM in regulating transpiration, compartmentation, and efflux of $\mathrm{Na}^{+}$into the cell vacuoles in plants under SS and SS + MS.

\section{Conclusions}

Our results indicate that the inoculation of $P$. libanensis alone or in combination with $C$. claroideum could alleviate the deleterious effects of SS, MS or SS + MS in soil by improving plant growth, chlorophyll content and physiological status (electrolyte leakage, proline and malondialdehyde contents), therefore enhancing multiple stress (SS + MS) tolerance in $H$. annuus. Application of $P$. libanensis alone or in combination with $C$. claroideum also reduced the deleterious effects of multiple stresses by decreasing $\mathrm{Ni}$ and $\mathrm{Na}^{+}$uptake under SS + MS. The findings conclusively suggest that inoculation of $\mathrm{PBB}$, AMF or their combination might have significant potential to improve plant growth and phytostabilization efficiency in $\mathrm{Ni}$ contaminated saline soils. However, since this study was conducted under greenhouse controlled 
conditions, further research in metal and salt affected field soil is necessary to utilize $P$. libanensis and $C$. claroideum as efficient bioinoculants for improving phytostabilization process in natural ecosystems.

\section{References}

[1] R. Munns, M. Tester, Mechanisms of salinity tolerance, Annu. Rev. Plant Biol. 59 (2008) 651-681.

[2] T.J. Purakayastha, A. Mandal, S. Kumari, Phytoremediation of metal- and salt-affected soils, in: S. Arora, A. Singh, Y. Singh (Eds.), Bioremediation of Salt Affected Soils: An Indian Perspective, Springer, Cham, 2017.

[3] Y. Ma, M. Rajkumar, C. Zhang, H. Freitas, Inoculation of Brassica oxyrrhina with plant growth promoting bacteria for the improvement of heavy metal phytoremediation under drought conditions, J. Hazard. Mater. 320 (2016) 36-44.

[4] Y. Ma, M. Rajkumar, A. Moreno, C. Zhang, H. Freitas, Serpentine endophytic bacterium Pseudomonas azotoformans ASS1 accelerates phytoremediation of soil metals under drought stress, Chemosphere 185 (2017) 75-85.

[5] M. Rajkumar, L. Benedict Bruno, J. Rajesh Banu, Alleviation of environmental stress in plants: the role of beneficial Pseudomonas spp, Crit. Rev. Environ. Sci. Technol. 47 (2017) 372-407.

[6] C. Dimkpa, T. Weinand, F. Ash, Plant-rhizobacteria interactions alleviate abiotic stress conditions, Plant Cell Environ. 32 (2009) 1682-1694.

[7] Y. Ma, M.N.V. Prasad, M. Rajkumar, H. Freitas, Plant growth promoting rhizobacteria and endophytes accelerate phytoremediation of metalliferous soils, Biotechnol. Adv. 29 (2011) 248-258.

[8] S. Shilev, E.D. Sancho, M. Benlloch-González, Rhizospheric bacteria alleviate salt produced stress in sunflower, J. Environ. Manage. 95 (Suppl) (2012) S37-41.

[9] D. Rojas-Tapias, A. Moreno-Galvan, S. Pardo-Diaz, M. Obando, D. Rivera, R. Bonilla, Effect of inoculation with plant growth-promoting bacteria (PGPB) on amelioration of saline stress in maize (Zea mays), Appl. Soil Ecol. 61 (2012) 264-272.

[10] Y. Ma, M. Rajkumar, I. Rocha, R.S. Oliveira, H. Freitas, Serpentine bacteria influence metal translocation and bioconcentration of Brassica juncea and Ricinus communis grown in multi-metal polluted soils, Front. Plant Sci. 5 (2015) 757.

[11] Y. Ma, R.S. Oliveira, F.J. Nai, M. Rajkumar, Y.M. Luo, I. Rocha, H. Freitas, The hyperaccumulator Sedum plumbizincicola harbors metal-resistant endophytic bacteria that improve its phytoextraction capacity in multi-metal contaminated soil, J. Environ. Manag. 156 (2015) 62-69.

[12] M.E. Abdelaziz, D. Kim, S. Ali, N.V. Fedoroff, S. Al-Babili, The endophytic fungus Piriformospora indica enhances Arabidopsis thaliana growth and modulates $\mathrm{Na}^{+} / \mathrm{K}^{+}$ homeostasis under salt stress conditions, Plant Sci. 263 (2017) 107-115.

[13] S. Patel, H.N. Jinal, N. Amaresan, Isolation and characterization of drought resistance bacteria for plant growth promoting properties and their effect on chilli (Capsicum annuum) seedling under salt stress, Biocatal. Agric. Biotechnol. 12 (2017) 85-89.

[14] P.K. Mishra, S. Mishra, S.C. Bisht, G. Selvakumar, S. Kundu, J.K. Bisht, H.S. Gupta, Isolation, molecular characterization and growth-promotion activities of a cold tolerant bacterium Pseudomonas sp. NARs9 (MTCC9002) from the Indian Himalayas, Biol. Res. 42 (2009) 305-313.

[15] M. Honma, T. Shimomura, Metabolism of 1-aminocyclopropane-1-carboxylic acid, Agric. Biol. Chem. 42 (1978) 1825-1831.

[16] J.M. Bric, R.M. Bostock, S.E. Silversone, Rapid in situ assay for indole acetic acid production by bacteria immobilization on a nitrocellulose membrane, Appl. Environ. Microb. 57 (1991) 535-538.

[17] B. Schwyn, J.B. Neilands, Universal chemical assay for the detection and determination of siderophores, Anal. Biochem. 160 (1987) 47-56.

[18] W.V.B. Sundara-Rao, M.K. Sinha, Phosphate dissolving microorganisms in the soil and rhizosphere, Indian J. Agr. Sci. 33 (1963) 272-278.

[19] J.H. Park, N. Bolan, M. Mallavarapu, R. Naidu, Isolation of phosphate solubilizing bacteria and their potential for lead immobilization in soil, J. Hazard. Mater. 185 (2011) 829-836.

[20] B.E. Christensen, J. Kjosbakken, O. Simdsrod, Partial chemical and physical characterization of two extracellular polysaccharides produced by marine, periphytic Pseudomonas sp strain NCMB 2021, Appl. Environ. Mirobiol. 50 (1985) 837-845.

[21] J. Dobereiner, I.E. Marriel, M. Nery, Ecological distribution of Spirillum lipoferum Beijerinck, Can. J. Microbiol. 22 (1976) 1464-1473.

[22] N. Sahin, I. Gökler, A.Ü. Tamer, Isolation, characterization and numerical taxonomy of novel oxalate-oxidizing bacteria, J. Microbiol. 40 (2) (2002) 109-118.

[23] R.S. Oliveira, P.M.L. Castro, J.C. Dodd, M. Vosátka, Different native arbuscular mycorrhizal fungi influence the coexistence of two plant species in a highly alkaline anthropogenic sediment, Plant Soil 287 (2006) 209-221.

[24] A.A. Safari Sinegani, K. Khalilikhah, Phytoextraction of lead by Helianthus annuus: effect of mobilising agent application time, Plant Soil Environ. 10 (2008) 434-440.
[25] Y. Ma, M. Rajkumar, Y.M. Luo, H. Freitas, Inoculation of endophytic bacteria on host and non-host plants - effects on plant growth and Ni uptake, J. Hazard. Mater. 196 (2011) 230-237.

[26] J.M. Phillips, D.S. Hayman, Improved procedures for clearing roots and staining parasitic vesicular-arbuscular mycorrhizal fungi for rapid assessment of infection, Trans. Br. Mycol. Soc. 55 (1970) 158-161.

[27] R.S. Oliveira, M. Vosátka, J.C. Dodd, P.M.L. Castro, Studies on the diversity of arbuscular mycorrhizal fungi and the efficacy of two native isolates in a highly alkaline anthropogenic sediment, Mycorrhiza 16 (2005) 23-31.

[28] M. Giovannetti, B. Mosse, An evaluation of techniques for measuring vesicular arbuscular mycorrhizal infection in roots, New Phytol. 84 (1980) 489-500.

[29] Z.M. Kuramshina, J.V. Smirnova, R.M. Khairullin, The effect of pre-inoculation of seeds by cells of bacteria, in: J.L. Lopez-Bonilla, M.I. Abdullin, G.E. Zaikov (Eds.) Physical Chemistry for the Chemical and Biochemical Sciences, 2016.

[30] R. Munns, S. Husain, A.R. Rivelli, R.A. James, A.G. Condon, M.P. Lindsay, E.S. Lagudah, D.P. Schachtman, R.A. Hare, Avenues for increasing salt tolerance of crops, and the role of physiologically based selection traits, Plant Soil 247 (2002) 93-105.

[31] H. Lichtenthaler, A. Wellburn, Determination of total carotenoids and chlorophylls a and b of leaf extracts in different solvents, Biochem. Soc. Trans. 603 (1983) 591-592.

[32] A. Giannakoula, M. Moustakas, P. Mylona, L. Papadakis, T. Yupsanis, Aluminum tolerance in maize is correlated with increased levels of mineral nutrients, carbohydrates and proline, and decreased levels of lipid peroxidation and $\mathrm{Al}$ accumulation, J. Plant Physiol. 165 (2008) 385-396.

[33] L.S. Bates, R.P. Waldren, I.D. Teare, Rapid determination of free proline for waterstress studies, Plant Soil 39 (1) (1973) 205-207.

[34] P.S. Campos, V. Quartin, J.C. Ramalho, M.A. Nunes, Electrolyte leakage and lipid degradation account for cold sensitivity in leaves of Coffea sp. plants, J. Plant Physiol. 160 (3) (2003) 283-292.

[35] Y. Ma, M. Rajkumar, H. Freitas, Improvement of plant growth and nickel uptake by nickel resistant-plant growth promoting bacteria, J. Hazard. Mater. 166 (2009) 1154-1161.

[36] S. Cui, Q. Zhou, L. Chao, Potential hyperaccumulation of $\mathrm{Pb}, \mathrm{Zn}, \mathrm{Cu}$ and $\mathrm{Cd}$ in endurant plants distributed in an old smeltery, northeast China, Environ. Geol. 51 (2007) 1043-1048.

[37] N. Suzuki, R.M. Rivero, V. Shulaev, E. Blumwald, R. Mittler, Abiotic and biotic stress combinations, New Phytol. 203 (2014) 32-43.

[38] P.E. Verslues, M. Agarwal, S. Katiyar-Agarwal, J. Zhu, J.K. Zhu, Methods and concepts in quantifying resistance to drought, salt and freezing, abiotic stresses that affect plant water status, Plant J. 45 (2006) 523-539.

[39] V. Demidchik, D. Straltsova, S.S. Medvedev, G.A. Pozhvanov, A. Sokolik, V. Yurin, Stress-induced electrolyte leakage: the role of $\mathrm{K}^{+}$-permeable channels and involvement in programmed cell death and metabolic adjustment, J. Exp. Bot. 65 (5 (2014) 1259-1270.

[40] H. Karlidag, E. Yildirim, M. Turan, M. Pehluvan, F. Donmez, Plant growth promoting rhizobacteria mitigate deleterious effects of salt stress on strawberry plants (Fragaria ananassa), Hortic. Sci. 48 (2013) 563-567.

[41] F. Aliya, B. Asghari, Role of plant growth-promoting rhizobacteria (PGPR), biochar, and chemical fertilizer under salinity stress, Comm. Soil Sci. Plant Anal. 47 (17) (2016) 1985-1993.

[42] K. Taïbi, F. Taïbi, L. Ait Abderrahim, A. Ennajah, M. Belkhodja, J.M. Mulet, Effect of salt stress on growth, chlorophyll content, lipid peroxidation and antioxidant defence systems in Phaseolus vulgaris L, S. Afr. J. Bot. 105 (2016) 306-312.

[43] S.H. Habib, H. Kausar, H.M. Saud, Plant growth-promoting rhizobacteria enhance salinity stress tolerance in okra through ROS-scavenging enzymes, Biomed Res. Int. 2016 (2016) 6284547.

[44] H.B. Bal, L. Nayak, S. Das, T.K. Adhya, Isolation of ACC deaminase producing PGPR from rice rhizosphere and evaluating their plant growth promoting activity under salt stress, Plant Soil 366 (2013) 93-105.

[45] S. Ali, T.C. Charles, B.R. Glick, Amelioration of high salinity stress damage by plant growth-promoting bacterial endophytes that contain ACC deaminase, Plant Physiol. Biochem. 80 (2014) 160-167.

[46] S.-M. Kang, A.L. Khan, M. Waqas, Y.-H. You, J.-H. Kim, J.-G. Kim, M. Hamayun, I.J. Lee, Plant growth-promoting rhizobacteria reduce adverse effects of salinity and osmotic stress by regulating phytohormones and antioxidants in Cucumis sativus, $\mathrm{J}$. Plant Interact. 9 (2014) 673-682.

[47] P.M. Hasegawa, R.A. Bressan, J.K. Zhu, H.J. Bohnert, Plant cellular and molecular responses to high salinity, Annu. Rev. Plant Biol. 51 (2000) 463-499.

[48] Z. Huang, L. Zhao, D. Chen, M. Liang, Z. Liu, H. Shao, X. Long, Salt stress encourages proline accumulation by regulating proline biosynthesis and degradation in Jerusalem artichoke plantlets, PLoS One 8 (4) (2013) e62085.

[49] M. Ashraf, M.R. Foolad, Roles of glycine betaine and proline in improving plant abiotic stress resistance, Environ. Exp. Bot. 59 (2007) 206-216.

[50] M. Ashraf, P.J.C. Harris, Photosynthesis under stressful environments: an overview, Photosynthetica 51 (2013) 163-190.

[51] K. Naeem, B. Asghari, Z. Peiman, Effects of exogenously applied plant growth regulators in combination with PGPR on the physiology and root growth of chickpea (Cicer arietinum) and their role in drought tolerance, J. Plant Interact. 13 (1) (2018) 239-247.

[52] R.P. Singh, P.N. Jha, The PGPR Stenotrophomonas maltophilia SBP-9 augments resistance against biotic and abiotic stress in wheat plants, Front. Microbiol. 8 (2017) 1945.

[53] Y. Lee, R. Krishnamoorthy, G. Selvakumar, K. Kim, T. Sa, Alleviation of salt stress in maize plant by co-inoculation of arbuscular mycorrhizal fungi and Methylobacterium oryzae CBMB20, J. Korean Soc. Appl. Biol. Chem. 58 (4) (2015) 533-540. 
[54] M. Ozden, U. Demirel, A. Kahraman, Effects of proline on antioxidant system in leaves of grapevine (Vitis vinifera L.) exposed to oxidative stress by $\mathrm{H}_{2} \mathrm{O}_{2}$, Sci. Hortic. 119 (2) (2009) 163-168.

[55] R.P. Singh, P.f.N. Jha, A halotolerant bacterium Bacillus licheniformis HSW-16 augments induced systemic tolerance to salt stress in wheat plant (Triticum aestivum), Front. Plant Sci. 7 (2016) 1890

[56] L. Hu, L. Chen, L. Liu, Y. Lou, E. Amombo, J. Fu, Metabolic acclimation of source and sink tissues to salinity stress in bermudagrass (Cynodon dactylon), Physiol. Plant. 155 (2014) 166-179.

[57] Z. Leblebici, A. Aksoy, F. Duman, Influence of salinity on the growth and heavy metal accumulation capacity of Spirodela polyrrhiza (Lemnaceae), Turk. J. Biol. 35 (2) (2011) 215-220.

[58] P.M. Joshi, A.A. Juwarkar, In vivo studies to elucidate the role of extracellular polymeric substances from Azotobacter in immobilization of heavy metals, Environ.

Sci. Technol. 43 (2009) 5884-5889.

[59] A.K. Shanker, V. Ravichandran, G. Pathmanabhan, Phytoaccumulation of chromium by some multipurpose tree seedlings, Agrofor. Syst. 64 (2005) 83-87.

[60] H.S. Han, K.D. Lee, Physiological responses of soybean-inoculation of Bradyrhizobium japonicum with PGPR in saline soil conditions, Res. J. Agric. Biol. Sci. 1 (2005) 216-221.

[61] S.M. Nadeem, Z.A. Zahir, M. Naveed, M. Arshad, S.M. Shahzad, Variation in growth and ion uptake of maize due to inoculation with plant growth promoting rhizobacteria under salt stress, Soil Environ. 25 (2006) 78-84.

[62] G. Shah, M. Jan, M. Afreen, M. Anees, S. Rehman, M.K. Daud, I. Malook, M. Jamil, Halophilic bacteria mediated phytoremediation of salt-affected soils cultivated with rice, J. Geochem. Explor. 174 (2017) 59-65.

[63] M.P. Apse, E. Blumwald, $\mathrm{Na}^{+}$transport in plants, FEBS Lett. 581 (12) (2007) $2247-2254$. 